\title{
Review
}

\section{Soluble transferrin receptor for the evaluation of erythropoiesis and iron status}

\author{
Yves Beguin*,1 \\ Department of Medicine, Division of Hematology, University of Liège, CHU Sart Tilman, 4000 Liège, Belgium
}

Received 14 November 2002; received in revised form 12 December 2002; accepted 17 December 2002

\begin{abstract}
Iron transport in the plasma is carried out by transferrin, which donates iron to cells through its interaction with a specific membrane receptor, the transferrin receptor (TfR). A soluble form of the TfR (sTfR) has been identified in animal and human serum. Soluble TfR is a truncated monomer of tissue receptor, lacking its first 100 amino acids, which circulates in the form of a complex of transferrin and its receptor. The erythroblasts rather than reticulocytes are the main source of serum sTfR. Serum sTfR levels average $5.0 \pm 1.0 \mathrm{mg} / \mathrm{l}$ in normal subjects but the various commercial assays give disparate values because of the lack of an international standard. The most important determinant of sTfR levels appears to be marrow erythropoietic activity which can cause variations up to 8 times below and up to 20 times above average normal values. Soluble TfR levels are decreased in situations characterized by diminished erythropoietic activity, and are increased when erythropoiesis is stimulated by hemolysis or ineffective erythropoiesis. Measurements of sTfR are very helpful to investigate the pathophysiology of anemia, quantitatively evaluating the absolute rate of erythropoiesis and the adequacy of marrow proliferative capacity for any given degree of anemia, and to monitor the erythropoietic response to various forms of therapy, in particular allowing to predict response early when changes in hemoglobin are not yet apparent. Iron status also influences sTfR levels, which are considerably elevated in iron deficiency anemia but remain normal in the anemia of inflammation, and thus may be of considerable help in the differential diagnosis of microcytic anemia. This is particularly useful to identify concomitant iron deficiency in a patient with inflammation because ferritin values are then generally normal. Elevated STfR levels are also the characteristic feature of functional iron deficiency, a situation defined by tissue iron deficiency despite adequate iron stores. The sTfR/ferritin ratio can thus describe iron availability over a wide range of iron stores. With the exception of chronic lymphocytic leukemia (CLL) and high-grade non-Hodgkin's lymphoma and possibly hepatocellular carcinoma, sTfR levels are not increased in patients with malignancies. We conclude that soluble TfR represents a valuable quantitative assay of marrow erythropoietic activity as well as a marker of tissue iron deficiency.
\end{abstract}

(C) 2003 Elsevier Science B.V. All rights reserved.

Keywords: Transferrin receptor; Erythropoiesis; Iron deficiency

\section{Introduction}

* Tel.: +32-4-366-7690; fax: +32-4-366-8855.

E-mail address: yves.beguin@chu.ulg.ac.be (Y. Beguin).

${ }^{1}$ Yves Beguin is Research Director of the National Fund for Scientific Research (FNRS, Belgium).

Iron transport in the plasma is carried out by transferrin, which donates iron to cells through its interaction with a specific membrane receptor. The 
transferrin receptor (TfR) is a 760-amino-acid glycoprotein. The functional receptor is composed of two such monomers, linked by two disulfide bridges to form a molecule of 190,000 Da. Virtually all cells, except mature red cells, have TfR on their surface, but the largest numbers are in the erythron, placenta and liver. In a normal adult, about $80 \%$ of TfR are in the erythroid marrow. Receptor density on proliferating cells is related to the availability of iron as deprivation of iron results in prompt induction of TfR synthesis whereas excess iron suppresses TfR numbers. Therefore, the total mass of cellular TfR depends both on the number of erythroid precursors in the bone marrow and on the number of TfR per cell, a function of the iron status of the cell.

A circulating form of TfR has been found in human as well as animal serum. Serum TfR (sTfR) is a soluble truncated monomer of tissue receptor, lacking its first 100 amino acids, which circulates in the form of a complex of transferrin and its receptor [1]. A possible conformation is two receptor monomers $(85 \mathrm{kDa})$ binding to one transferrin molecule $(80$ $\mathrm{kDa}$ ) to give a total MW of around $250 \mathrm{kDa}$. A very small amount (although this may vary with the patient's diagnosis) of circulating TfR is in the form of an intact dimer in exosomes [2]. Soluble TfR is produced by proteolysis, mediated by a membraneassociated serine protease that occurs mostly at the surface of exosomes within the multivesicular body prior to exocytosis [3]. The bulk of sTfR measured in serum is proportional to the mass of cellular TfR [4] and originates mostly from erythroblasts and to a lesser extent from reticulocytes [5].

In this review, we will highlight the value of soluble sTfR as a quantitative measure of erythropoietic activity and as a marker of tissue iron deficiency. This will be extensively illustrated by presenting numerous examples of the practical use of this assay in the evaluation of erythropoiesis and/or iron status in an individual as well as in defined populations of patients. Potential pitfalls in the interpretation of sTfR values will be discussed.

\section{Soluble $T f R$ in normal subjects}

Kohgo et al. [6] and Beguin et al. [7] were the first to measure sTfR quantitatively in human and rat serum, respectively. A number of quantitative assays have been set up to measure sTfR levels in biological fluids such as culture supernatants and plasma or serum. Some have been developed in research laboratories but several are now commercially available. The performance of these assays is highly variable but the major problem is the lack of an international standard. Therefore, although levels measured by various assays may correlate well, direct clinical comparison of values obtained with different assays is difficult. Using our assay, sTfR levels averaged $5.0 \pm 1.0 \mathrm{mg} / 1$ (mean \pm S.D.) in a group of 165 normal human subjects and were remarkably stable over time in the same subject. No differences are observed with sex or age in the 18-80-year age range [8], but levels are somewhat higher in fetuses and newborns compared to adults. In the early postnatal period, sTfR levels are comparable to those of adults with marrow suppression, but they soon increase again so that infants [9] and adolescents [10] tend to have slightly higher sTfR levels than adults. Age-specific reference limits for children aged $0-4,4-10$ and $10-16$ years could be derived in a carefully selected group of healthy children from the observation of a continuous decline of sTfR values from birth to late adolescence [11].

\section{Soluble TfR and erythropoiesis}

\subsection{Soluble TfR and erythropoietic activity}

Erythropoietic activity has been found to be the most important determinant of sTfR levels [6,7, 12,13]. Decreased sTfR levels are found in situations characterized by erythroid hypoplasia (Fig. 1), such as hypertransfusion, chronic renal failure, severe aplastic anemia or after intensive chemotherapy [14]. Increased sTfR levels are seen in situations of stimulated erythropoiesis (Fig. 2), such as congenital dyserythropoietic anemia, hemolytic anemia, hereditary spherocytosis, sickle cell anemia, thalassemia major or intermedia, megaloblastic anemia or secondary polycythemia. Levels range from a minimum of about $0.5 \mathrm{mg} / \mathrm{l}$ - the contribution of nonerythroid tissueswhen erythropoiesis is totally absent, to about 100 $\mathrm{mg} / \mathrm{l}$ in severely anemic thalassemia patients [12]. The dependence of sTfR levels on the activity of the 


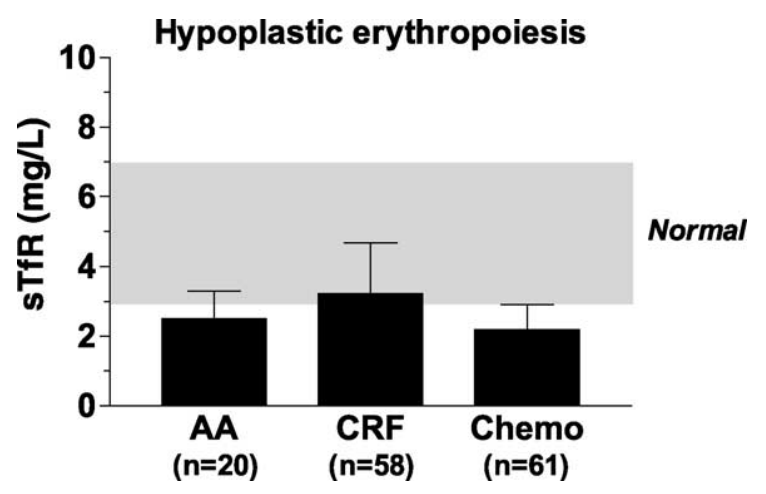

Fig. 1. Mean \pm S.D. sTfR levels in groups of patients with hypoplastic erythropoiesis, including severe aplastic anemia (AA), chronic renal failure (CRF), or after intensive chemotherapy (Chemo). The gray zone represents the reference interval in normal subjects.

erythron is further demonstrated by the strong correlation observed with ferrokinetic measurements of erythropoiesis. This has first been shown in rats with normal, suppressed, or stimulated erythropoiesis [7]. This has also been confirmed in humans in whom the relationship between mean erythron transferrin uptake (ETU) and mean sTfR level in groups of subjects with a variety of diagnoses is very close to the line of proportionality $[12,15]$. The greater precision and simpler methodology of sTfR determination should thus make it the method of choice to quantitate total erythropoiesis.

\subsection{Soluble TfR and pathophysiology of anemias}

Erythropoietin (Epo) production is regulated through a feedback system between the bone marrow and the kidney through which serum Epo levels increase exponentially in proportion to the degree of anemia. In the presence of a normal marrow stem cell reserve, erythropoiesis increases in proportion to Epo stimulation and thus sTfR also rise exponentially in response to anemia [15].

We thus constructed reference regressions representing the normal relationships between hematocrit (Hct) on the one hand, and Epo or sTfR on the other, based on normal subjects and patients with hemolytic anemia [15]. Based on these formulas, predicted $\log ($ Epo $)$ and $\log (\mathrm{sTfR})$ values were derived for each Hct, O/P ratios of observed/predicted $\log ($ Epo) or $\log (\mathrm{sTfR})$ were derived, and $95 \%$ confidence limits were obtained in order to define a range of reference values for individual $\mathrm{O} / \mathrm{P}$ ratios. These limits are $0.80-1.20$ for $\mathrm{O} / \mathrm{P}$ Epo and $0.90-1.10$ for $\mathrm{O} / \mathrm{P}$ sTfR. The pathophysiology of anemia can therefore be assessed by a simple determination of the patient's Hct, serum Epo and sTfR. These measurements are best expressed in relation to the degree of anemia to avoid gross overestimation of marrow proliferative capacity. When investigating a group of patients, this can be achieved by comparing patients and reference subjects (hemolytic anemia) by regression analysis. When studying an individual patient, this can be obtained by the $\mathrm{O} / \mathrm{P}$ ratio. Then not only the absolute rate but also the adequacy of Epo production $(\mathrm{O} / \mathrm{P}$ Epo) and of marrow response to Epo stimulation $(\mathrm{O} / \mathrm{P}$ sTfR) can be evaluated as appropriate or not for a given degree of anemia.

As shown in Table 1, three major patterns of erythropoiesis are described on the basis of the Hct, $\mathrm{O} / \mathrm{P}$ sTfR and O/P Epo, while the retic index and sTfR levels serve to separate major patterns into variants [15]. Normal Hct, O/P Epo and O/P TfR define a normal pattern of erythropoiesis. The sTfR value helps differentiate a variant of compensated hemolysis in which sTfR is increased. Decreased Hct and normal $\mathrm{O} / \mathrm{P}$ Epo and O/P sTfR characterize a pattern of "hyperdestruction". The reticulocyte index helps break this group down into two variants of "hemolysis" (index >3) and "ineffective erythropoiesis"

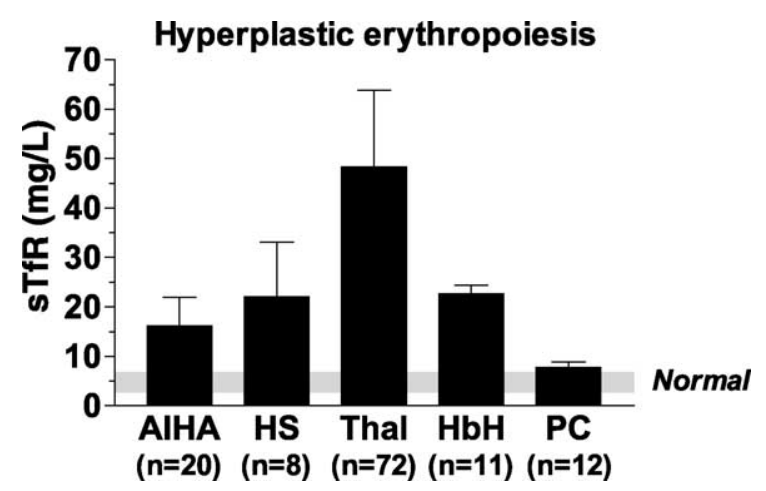

Fig. 2. Mean \pm 1 S.D. sTfR levels in groups of patients with hyperplastic erythropoiesis, including autoimmune hemolytic anemia (AIHA), hereditary spherocytosis (HS), $\beta$-thalassemia major (Thal), $\mathrm{HbH}$ disease $(\mathrm{HbH})$, or polycythemia (PC). The gray zone represents the reference interval in normal subjects. 
Table 1

Patterns of erythropoiesis in the investigation of the pathophysiology of anemia based on the hematocrit, the reticulocyte index, serum sTfR, O/ $\mathrm{P}$ (observed/predicted) sTfR and O/P Epo

\begin{tabular}{|c|c|c|c|c|c|c|c|}
\hline $\begin{array}{l}\text { Erythropoiesis } \\
\text { pattern }\end{array}$ & Main characteristics & Het & $\mathrm{O} / \mathrm{P}$ sTfR & O/P Epo & sTfR & Retic index ${ }^{a}$ & Example \\
\hline \multirow[t]{2}{*}{ Normal } & Normal & $\mathrm{N}$ & $\mathrm{N}$ & $\mathrm{N}$ & $\mathrm{N}$ & $\mathrm{N}$ & Normal \\
\hline & $\begin{array}{l}\text { Compensated } \\
\text { hemolysis }\end{array}$ & $\mathrm{N}$ & $\mathrm{N}$ & $\mathrm{N}$ & $\uparrow$ & $\uparrow$ & $\begin{array}{l}\text { Hereditary } \\
\text { spherocytosis }\end{array}$ \\
\hline \multirow[t]{2}{*}{ Hyperdestruction } & Hemolysis & $\downarrow$ & $\mathrm{N}$ & $\mathrm{N}$ & $\uparrow$ & $\uparrow$ & AIHA \\
\hline & $\begin{array}{l}\text { Ineffective } \\
\text { erythropoiesis }\end{array}$ & $\downarrow$ & $\mathrm{N}$ & $\mathrm{N}$ & $\uparrow$ & $\downarrow$ & Thalassemia \\
\hline \multirow[t]{2}{*}{ Hypoproliferation } & Marrow failure & $\downarrow$ & $\downarrow$ & $\mathrm{N}$ & $\downarrow$ & $\downarrow$ & Aplastic anemia \\
\hline & $\begin{array}{l}\text { Defective Epo } \\
\text { production }\end{array}$ & $\downarrow$ & $\downarrow$ & $\downarrow$ & $\downarrow$ & $\downarrow$ & Renal failure \\
\hline \multirow[t]{2}{*}{ Mixed disorder } & Marrow failure & $\downarrow$ & $\downarrow$ & $\mathrm{N}$ & $\mathrm{N}-\uparrow$ & $\downarrow$ & MDS \\
\hline & $\begin{array}{l}\text { Defective Epo } \\
\text { production }\end{array}$ & $\downarrow$ & $\downarrow$ & $\downarrow$ & $\mathrm{N}-\uparrow$ & $\downarrow$ & Cancer \\
\hline
\end{tabular}

AIHA = autoimmune hemolytic anemia. MDS = Myelodysplastic syndrome.

${ }^{a}$ Retic index: $<2$ is low, $>3$ is high.

(index $<2$ ). The pattern of "erythroid marrow hypoproliferation" is defined by erythropoietic activity inadequately low for the degree of anemia (decreased $\mathrm{O} / \mathrm{P}$ sTfR). This can be related to defective Epo production (low $\mathrm{O} / \mathrm{P}$ Epo) or intrinsic marrow failure (normal O/P Epo). Marrow hypoproliferation can be absolute (decreased sTfR), i.e. "hypoproliferative anemia", or relative (normal/increased sTfR), termed "mixed disorder of erythropoiesis", i.e. with both hyperdestruction and hypoproliferation components. The model is thus very useful for detecting the presence of multiple mechanisms of anemia in the same patient, particularly a component of hypoproliferation being associated with hyperdestruction.

This functional classification of anemia reveals that a same clinical diagnosis may be associated with different patterns of erythropoiesis, while a same pattern of erythropoiesis can be seen across different clinical groups [15]. A typical example is the anemia of chronic disorders. Children with acute leukemia or solid tumors have adequate Epo production but profoundly suppressed erythropoiesis [16]. Patients with chronic lymphocytic leukemia (CLL) appear to have appropriate Epo production and erythroid marrow response for the degree of anemia, although erythropoiesis may become impaired in advanced stages [17]. A significant proportion of multiple myeloma patients has relative marrow failure in large part due to inadequate Epo production [18]. Defective iron sup- ply to the erythron rather than blunted Epo production is the major cause of anemia associated with systemiconset juvenile arthritis, resulting in elevated sTfR levels that return to normal following correction of anemia with intravenous (IV) iron [19].

\subsection{Soluble TfR and erythropoietic response to treat- ment}

Serum sTfR determinations are ideal for situations in which serial measurements of erythropoiesis are needed, for instance, after bone marrow transplantation. It has thus been possible to demonstrate that the development of erythropoiesis after autologous transplantation is determined by the overall marrow proliferative capacity and that Epo plays only a facilitating role, while after allogeneic transplantation, erythropoiesis depends on Epo production which remains inadequate for prolonged periods of time [14]. Compared to autologous bone marrow transplantation, the use of peripheral blood stem cells is associated with faster erythroid recovery and higher Epo consumption [20]. Soluble TfR may be used to monitor erythropoietic response to various forms of therapy, including the treatment of pure red cell aplasia with cyclosporine [21], of congenital Epodependent erythrocytosis with theophylline [22], or of thalassemia intermedia with butyrate [23]; the correction of megaloblastic anemia with cobalamin 
[21] or of iron deficiency anemia with iron [19]; the removal of excess iron by phlebotomy [24]; the response of aplastic anemia to immunosuppressive therapy [25]; the recovery of erythropoiesis after renal transplantation [26]; and the correction of hypersplenism following splenectomy [27].

Evaluation of marrow erythropoietic activity by sTfR is also valuable in patients receiving chronic transfusions. In thalassemia major, the recommended practice is to transfuse patients at a hemoglobin $(\mathrm{Hb})$ level of 9-11 g/dl to decrease iron absorption through erythroid marrow suppression, while avoiding excessive transfusion-associated iron overload. Measurements of sTfR levels have demonstrated that patients who undergo blood transfusions at regular intervals show better marrow suppression than those who are transfused more sporadically [28]. Nonetheless, this policy was not adequate in a number of patients who either were overtransfused or did not reach adequate inhibition of ineffective erythropoiesis [29]. The assay of sTfR may thus be useful to better individualize the transfusion regimen. The same conclusions were derived in patients with sickle cell anemia [30], although similar myelosuppression with increased fetal hemoglobin can be achieved with hydroxyurea [31].

Soluble TfR is of particular interest in assessing response to recombinant human erythropoietin (rHuEpo) in patients with chronic renal failure [32,33], aplastic anemia [34], pure red cell aplasia [35], thalassemia intermedia [36], cancer [37-39], myelodysplastic syndrome (MDS) [37,40], rheumatoid arthritis [41], genetic hemochromatosis [42] or in intensive care [43], as well as in normal subjects [44], autologous blood donors [45] and premature infants [46] or after stem cell transplantation [47,48]. Similarly, sTfR levels can be used to monitor how erythropoiesis subside after cessation of rHuEpo therapy [49]. Measurements of sTfR and calculated $\mathrm{sTfR} /$ ferritin ratios have also been proposed as possible probes to detect erythropoietin abuse in athletes [44], although lower rHuEpo doses inducing similar Hct changes over a longer period of time are not associated with sTfR changes [50]. Therefore, combining sTfR measurements into a multiparametric assessment of erythroid marrow function may improve the detection of rHuEpo abuse [50,51]. However, intermittent or continuous hypoxia [52] as achieved by a "living high-training low" program [53] also induce endogenous Epo-driven elevated sTfR values.

In response to rHuEpo, the erythroblast compartment is very slow to respond, expanding over a period of 6 weeks before reaching a steady state during which the $\mathrm{Hb}$ continue to rise [32]. The dose of rHuEpo needed to achieve response is highly variable because of such interfering factors as functional iron deficiency or inflammation. Early recognition of a low probability of hematologic response could help identify and correct specific causes of treatment failure or suggest rapid dose escalation, in order to hasten clinical improvement and avoid prolonged ineffective use of an expensive medication. Measurement of sTfR levels may play a major role in this area. In hemodialysis patients, a good prediction of response was obtained with baseline $\operatorname{sTfR}(<$ or $\geq 3.5 \mathrm{mg} / \mathrm{l})$ and fibrinogen, illustrating the importance of subclinical inflammation (higher fibrinogen) and functional iron deficiency (higher sTfR) in impairing response to rHuEpo [33]. In cancer patients, inadequately low serum Epo levels are associated with a much better chance of responding to treatment [38]. Evaluating the early erythropoietic response to rHuEpo before a significant change in Hct can be observed is also very helpful. In hemodialysis patients, a sTfR increment of at least $20 \%$ after 2 weeks secured a response in virtually $100 \%$ of the patients [33]. In cancer patients, several studies have shown that the hematologic response to rHuEpo was strongly associated with early increases of sTfR levels $(20-25 \%$ over baseline) after $1-2$ weeks of treatment [37-39]. A combination of baseline parameters and early changes observed after 2 weeks of rHuEpo may provide another useful approach. This has first be proposed in hemodialysis patients by combining baseline sTfR and fibrinogen with the 2-week sTfR increment [33]. In cancer patients, the combined use of baseline serum Epo and the 2-week sTfR increment proved to be very powerful, achieving an overall accuracy of $90 \%$ [38]. However, early prediction of response based on sTfR elevation early in the course of treatment will not be valid in patients in whom rHuEpo essentially stimulates ineffective erythropoiesis, for instance, some patients with MDS [37,40]. Nevertheless, failure to increase sTfR levels still strongly predict for treatment failure [54]. 


\section{Soluble TfR and iron status}

\subsection{Soluble TfR and iron status}

The iron status also influences sTfR levels in serum (Fig. 3) [7]. In subjects with elevated transferrin saturation [55,56], African iron overload $[57,58]$ or genetic hemochromatosis $[12,57,59]$, average sTfR levels are about $20 \%$ below those measured in normal subjects but most values are still within the normal range. Iron deficiency has a much stronger impact on sTfR levels [60]. Soluble TfR levels in severely anemic iron-deficient rats increase many folds over normal values, in proportion to the increase documented for erythron membrane receptors [7]. As compared to normal individuals, levels are marginally increased in nonanemic iron-deficient subjects but more dramatically so in patients with iron deficiency anemia $[12,13,61,62]$. In such patients, sTfR levels exhibit strong correlations with various red cell indices indicative of iron deficiency $[63,64]$ and are inversely related to serum ferritin [62]. The elevation of sTfR with iron deficiency has been confirmed by the evaluation of stainable marrow iron $[65,66]$.

Skikne et al. [67] have published an elegant study on the clinical utility of sTfR as a marker of the iron status. When normal volunteers underwent graded phlebotomy, ferritin decreased progressively while sTfR did not change much during the phase of storage

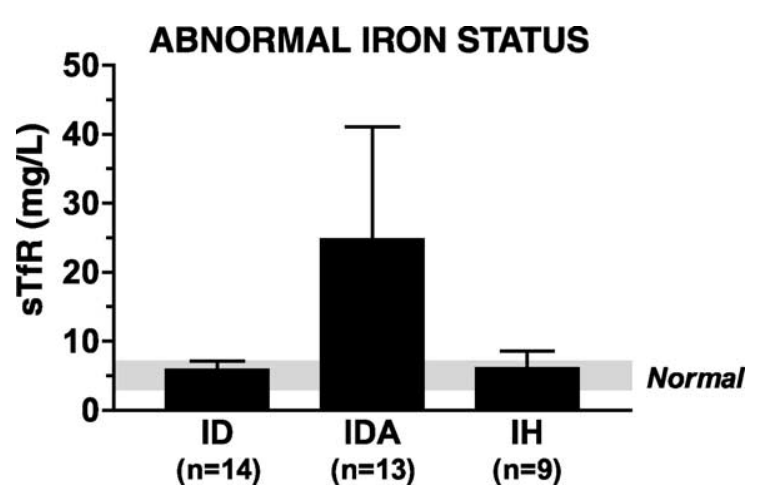

Fig. 3. Mean \pm 1 S.D. sTfR levels in groups of patients with abnormal iron status, including nonanemic iron deficiency (ID), iron deficiency anemia (IDA) and idiopathic hemochromatosis (IH). The gray zone represents the reference interval in normal subjects. iron depletion. However, sTfR increased significantly when marrow functional iron deficiency and anemia developed. Therefore, the iron status may be fully assessed by using serum ferritin as a measure of iron stores (storage iron depletion), sTfR as a measure of functional tissue iron deficiency (iron-deficient erythropoiesis), and hemoglobin as a measure of advanced iron deficiency (iron deficiency anemia). Because of the reciprocal relationship between serum sTfR and ferritin measurements, the ratio of $\mathrm{sTfR} /$ ferritin describes a perfect log-linear relationship to body iron over a wide range of normal and depleted iron stores [67]. This can also be obtained by the log of the ratio of sTfR to ferritin [68] or by the sTfR-ferritin index, the ratio of sTfR to $\log$ ferritin $[61,69]$. These ratios increase the sensitivity of sTfR in detecting latent iron deficiency. Conversely, for the assessment of ID anemia, the increase of sTfR usually does not exceed the diagnostic value of a low serum ferritin [70] or reticulocyte $\mathrm{Hb}$ content [71], or an elevated zinc protoporphyrin [72]. However, the gold standard for defining iron deficiency in these studies was very variable and not always adequate.

Iron supplementation returns sTfR to normal values but this may be preceded by some transient elevation, possibly reflecting expansion of the erythroid marrow [73]. In 2 double-blind placebo-controlled trials, nonanemic iron-depleted women receiving iron supplements showed a progressive and significant decrease in sTfR and sTfR/ferritin ratio $[74,75]$. Similar results were obtained in adolescent boys in whom a 50-day course of iron supplementation resulted in a significant, albeit small, drop of sTfR levels [10]. Intravenous iron therapy for severe anemia in systemic-onset juvenile chronic arthritis resulted in a correction of anemia together with a considerable drop in sTfR values $[19,76]$.

In another major study, apparently healthy nonanemic adults were supplemented with oral iron for 3 months to evaluate its effect on various parameters of iron status [77]. Iron supplementation did not induce any significant change in iron parameters in men, but reduced STfR levels and increased ferritin levels in a significant proportion of women. Changes in STfR occurred mainly in subjects with elevated values before supplementation. Of the 65 subjects, 25 were retrospectively judged to have had storage iron deple- 
tion or depletion of the functional compartment. This indicates that iron-deficient erythropoiesis may occur in subjects thought to be iron replete on the basis of ferritin values. The normal values of sTfR, ferritin and STfR-ferritin index should therefore be those obtained in these healthy adults after 3 months of iron supplementation had corrected subclinical iron depletion. In particular, the upper limit of normal sTfR values should be lowered to allow detection of incipient iron-deficient erythropoiesis. Iron stores may not need to be exhausted to have clinically relevant storage depletion. Subtle changes in functional iron supply have been illustrated in a study of obese patients undergoing a very-low-energy all-protein diet [78]. The serum iron and transferrin saturation fell sharply within 1 week and this was followed by moderate increases in sTfR correlating inversely with prior changes in serum iron. These results indicate that depressed serum iron, probably related to altered iron release by reticuloendothelial cells, induces functional tissue iron deficiency too short in duration to produce alterations in red blood cell indices. However, sTfR levels remained in the normal range and iron-deficient erythropoiesis could not have been detected if serial samples had not been obtained.

\subsection{Soluble TfR and inflammation}

As sTfR levels are not increased in patients with inflammation of unknown origin [79], the anemia of chronic disorders [80,81], HIV infection [82], acute infection [81,83] or in chronic liver disorders [81], they may help distinguish these clinical problems from iron deficiency (Table 2) [61,81,84-86]. Indeed, sTfR levels may not be increased despite evidence of functional iron deficiency as evidenced by elevated zinc protoporphyrin [72]. Furthermore, sTfR levels may decrease temporarily during acute inflammation

Table 2

Differential diagnosis between iron deficiency anemia (IDA), anemia of chronic disorder (ACD) and the combination of $\mathrm{ACD}+\mathrm{IDA}$

\begin{tabular}{llllll}
\hline & Hb & Serum iron & Ferritin & sTfR & sTfR/ferritin \\
\hline IDA & $\downarrow$ & $\downarrow$ & $\downarrow$ & $\uparrow$ & $\uparrow \uparrow$ \\
ACD & $\downarrow$ & $\downarrow$ & $\mathrm{N}-\uparrow$ & $\mathrm{N}$ & $\mathrm{N}$ \\
ACD + IDA & $\downarrow$ & $\downarrow$ & $\uparrow$ & $\uparrow$ & $\uparrow$ \\
\hline
\end{tabular}

[7]. Blunted Epo production and suppression of erythropoiesis by cytokines may be the reasons for the absence of elevation of sTfR in the anemia of inflammation.

On the other hand, patients with the anemia of chronic disorders may also have concomitant true iron deficiency and then show sTfR levels similarly elevated as in pure iron deficiency anemia (Table 2), even if these studies were not always based on a gold standard such as marrow iron determination [19,61, 76,87-91]. Values of sTfR decrease after adequate iron supplementation, independently of marrow iron stores, indicating that they are good indicators of functional iron deficiency [90]. Contrarily to serum ferritin, sTfR may thus prove to be a diagnostic test of iron deficiency in patients with inflammation. However, in some studies, sTfR levels could not distinguish accurately among patients with rheumatoid arthritis [92,93], inflammatory bowel disease [94] or other inflammatory disorders [95], those with or without iron deficiency. In addition, several studies have observed higher sTfR levels in iron-replete rheumatoid arthritis patients compared to normal subjects, even if they remain lower than in iron deficiency anemia [92,96-98]. Similarly, sTfR levels were increased in a large group of patients with systemic lupus erythematosus but no information is available on their iron status [99]. Levels were inversely related to $\mathrm{Hb}$ values, suggesting that they originated from stimulated erythropoiesis. Alternatively, this may indicate functional iron deficiency. Indeed, sTfR levels were elevated in cystic fibrosis patients with other signs of functional iron deficiency and were correlated with the degree of inflammation [100]. Therefore, the cutoff point for the diagnosis of depleted iron stores in a patient with inflammation could be higher than the upper limit of normal values [87].

In addition, serum ferritin, with cutoff points ranging from 30 to $100 \mu \mathrm{g} / \mathrm{l}$, in some studies offered an equivalent or even better prediction of bone marrow iron content $[88,93,97,101-103]$ or of $\mathrm{Hb}$ response to iron supplementation [86,104]. However, the combined use of sTfR and ferritin or the use of TfR/ferritin or $\mathrm{TfR} / \log$ ferritin ratios may increase the efficacy of sTfR in identifying iron deficiency in patients with chronic inflammation $[61,87,88,94,103]$. In particular, the $\log (\mathrm{sTfR} /$ ferritin) ratio may prove superior to the $\mathrm{sTfR} / \log$ ferritin index [68]. 


\section{Soluble TfR: a marker of iron status and/or erythropoiesis?}

Within the iron-replete range, sTfR correlates with $\mathrm{Hb}$ but not with markers of iron status such as transferrin saturation and ferritin [8,67,105-107]. An inverse correlation between sTfR and ferritin may even represent an association between erythropoietic activity and iron utilization for erythropoiesis rather than an effect of iron stores on TfR expression [107]. Soluble TfR is therefore only a marker of erythropoiesis when iron stores are adequate and available and additionally becomes a marker of iron status only when tissue iron deficiency (with or without adequate iron stores) occurs. While sTfR has proved to be a reliable marker of tissue iron deficiency, the interpretation of an individual value may be tricky in a patient in whom both changes in erythropoietic activity and iron status may occur simultaneously. In unselected populations of patients with a variety of diagnoses, the specificity and positive predictive value of an elevated sTfR level for the diagnosis of iron deficiency is low because many patients have other reasons (predominantly increased erythropoiesis) for it [65]. Combining sTfR and ferritin measurements may increase specificity but not sensitivity for the diagnosis of iron deficiency in such a population [108].

In patients with rheumatoid arthritis or other forms of anemia of chronic disorders, sTfR levels may well remain within the normal range even when iron stores are depleted [93] because cytokines or other factors also suppress erythropoiesis directly or through inhibition of Epo production. On the other hand, levels may be elevated even when iron stores are adequate [96] because marrow erythropoietic activity may be increased. Therefore, the relationship between iron status and sTfR levels in patients with inflammation depends on the severity of inflammation, the degree of anemia, the adequacy of Epo production and the effect of cytokines on marrow activity.

In other situations as well, it may be difficult to distinguish the respective influence of erythropoiesis and iron deficiency on sTfR levels. Patients with chronic liver disease may have elevated sTfR levels when they experience either iron deficiency or stimulated erythropoiesis in response to hemolysis or hemorrhage [109]. Renal failure patients have low sTfR levels as a result of erythroid hypoplasia $[12,42]$ and iron deficiency is then associated with a relative elevation of sTfR levels that nevertheless remain within the normal range $[33,110]$. Active malaria is associated with changes in erythropoietic activity brought about by hemolysis (which would tend to increase sTfR levels) as well as inflammation (which would rather decrease sTfR levels). The predominant effect was shown to be suppression of erythropoiesis by inflammation in active malaria, resulting in decreased sTfR levels [111-113], and appropriate marrow response to mild anemia in asymptomatic infection, with elevated sTfR levels [114,115]. Thus the diagnostic value of sTfR levels for iron deficiency may be impaired in individuals living in highly endemic areas for malaria $[116,117]$.

The interpretation of sTfR values could be even more difficult in patients treated with rHuEpo, where erythropoietic response is often associated with functional iron deficiency. If sTfR was mostly a marker of functional iron deficiency induced by rHuEpo, it should increase more consistently in nonresponders (primary cause of failure is functional iron deficiency) than in responders: in fact the reverse is true $[33,118]$. In addition, sTfR increments correlate well with later hematocrit increases [32], whereas levels are not different in patients with low or high ferritin [119] and correction of iron deficiency with oral iron is associated with little changes $[118,120]$. Furthermore, the elevation of sTfR in response to rHuEpo is larger in iron overloaded rats than in normal animals who develop functional iron deficiency [121]. Therefore sTfR remains predominantly a marker of erythroid response to rHuEpo.

Another situation where changes in iron status and erythropoiesis interact is pregnancy. Actually, sTfR levels are decreased in the first two trimesters, normalize in the first part of the 3rd trimester, and are slightly increased in late pregnancy and the early postpartum [122-125]. These changes in erythropoietic activity are still well apparent after carefully excluding irondeficient women [126], parallel those in Epo production [122] and reticulocytes [126], and thus explain known alterations in the red cell mass throughout pregnancy. On the other hand, some studies have found that depletion of iron stores also produced a moderate elevation of sTfR over levels observed in non-iron-deficient pregnancies [122,127], particularly at time of labor [128]. Others have found that among 
anemic as well as among nonanemic pregnancies, sTfR values are not influenced by iron stores $[82,124]$. Thus, elevated sTfR levels in late third trimester may help identify iron-deficient erythropoiesis with satisfactory specificity but low sensitivity, but reduced erythropoiesis limits the possibility of detecting iron deficiency in the rest of pregnancy $[123,128,129]$.

\section{Soluble TfR as a tumor marker}

Increased expression of transferrin receptors has been documented on the surface of malignant tumors as compared to their normal counterparts. A number of studies have evaluated sTfR levels in erythroid (Fig. 4) as well as nonerythroid malignancies (Fig. 5). Soluble TfR levels are elevated in patients with myelofibrosis and myeloproliferative disorders, but are essentially within the normal range in chronic myelogenous leukemia or essential thrombocythemia, which is in keeping with our understanding of erythropoiesis in these disorders $[12,130]$. Patients with MDS may have decreased, normal or elevated levels, reflecting the various patterns of erythropoiesis encountered in these disorders $[12,15,131,132]$. In patients with polycythemia vera, sTfR levels may be considerably elevated [12], although this may be partly because of phlebotomy-induced iron depletion.

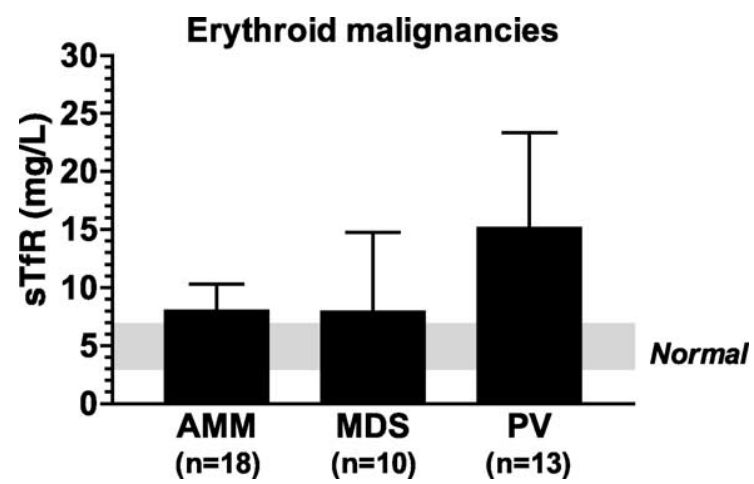

Fig. 4. Mean \pm 1 S.D. sTfR levels in groups of patients with malignancies involving the erythron, including agnogenic myeloid metaplasia (AMM), myelodysplastic syndrome (MDS) and polycythemia vera (PV). The gray zone represents the reference interval in normal subjects.

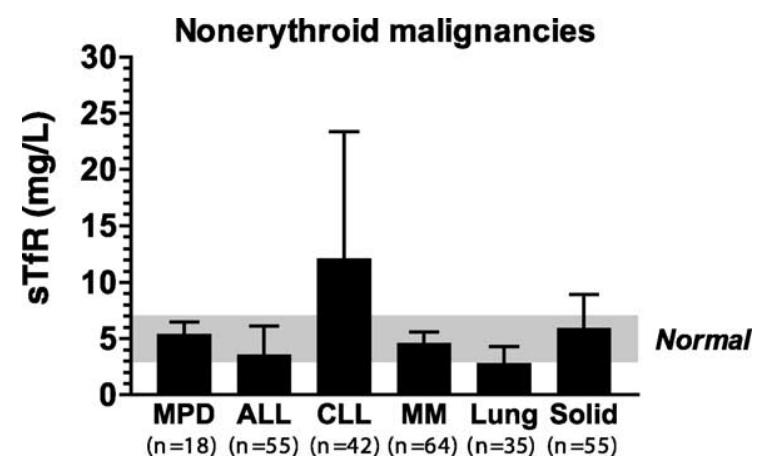

Fig. 5. Mean \pm 1 S.D. sTfR levels in groups of patients with nonerythroid malignancies, including myeloproliferative disorders (MPD), acute lymphoblastic leukemia (ALL), chronic lymphocytic leukemia (CLL), multiple myeloma (MM), lung cancer (Lung) and miscellaneous solid tumors (Solid). The gray zone represents the reference interval in normal subjects.

Soluble TfR levels are normal or decreased in patients with solid tumors $[12,16,133]$, with the possible exception of those with hepatocellular carcinoma [134]. Levels in acute leukemia have been found to be decreased at diagnosis and during chemotherapy $[12,16,130,135]$. Patients with many lymphoid malignancies, including hairy cell leukemia and multiple myeloma, have been found to have normal sTfR values, but this represents relative marrow failure for the degree of anemia $[12,18,130,135]$. However, levels may be considerably elevated in chronic lymphocytic leukemia $[17,130]$. The significance of this is unclear. On the one hand, sTfR levels are not increased beyond what is expected if the bone marrow is capable of responding adequately to an appropriate Epo stimulation for the degree of anemia [17]. This would indicate that the pathogenesis of anemia in CLL is in large part related to hemolysis and/or hypersplenism. On the other hand, sTfR correlated strongly with the levels of other soluble receptors, including CD23, a marker of the tumor burden. Appropriate sTfR levels for the degree of anemia could in fact result from an inadequately small amount of erythropoietic cell-derived sTfR with an exaggerated release by malignant lymphocytes. In patients with high-grade non-Hodgkin's lymphoma, elevated sTfR levels have been observed, which correlate with the tumor burden and clinical stage and normalize in patients responding to chemotherapy $[135,136]$. In 
conclusion, sTfR derived from tumor cells do not contribute significantly to overall sTfR levels, with the possible exception of non-Hodgkin's lymphoma, CLL and hepatocellular carcinoma.

\section{References}

[1] Shih YJ, Baynes RD, Hudson BG, Flowers CH, Skikne BS, Cook JD. Serum transferrin receptor is a truncated form of tissue receptor. J Biol Chem 1990;265:19077-81.

[2] Johnstone RM. The Jeanne Manery-Fisher Memorial Lecture 1991. Maturation of reticulocytes: formation of exosomes as a mechanism for shedding membrane proteins. Biochem Cell Biol 1992;70:179-90.

[3] Baynes RD, Shih YJ, Cook JD. Mechanism of production of the serum transferrin receptor. Adv Exp Med Biol 1994;356: $61-8$.

[4] R'Zik S, Loo M, Beguin Y. Reticulocyte transferrin receptor (TfR) expression and contribution to soluble TfR levels. Haematologica 2001;86:244-51.

[5] R'Zik S, Beguin Y. Serum soluble transferrin receptor concentration is an accurate estimate of the mass of tissue receptors. Exp Hematol 2001;29:677-85.

[6] Kohgo Y, Nishisato T, Kondo H, Tsushima N, Niitsu Y, Urushizaki I. Circulating transferrin receptor in human serum. Br J Haematol 1986;64:277-81.

[7] Beguin Y, Huebers HA, Josephson B, Finch CA. Transferrin receptors in rat plasma. Proc Natl Acad Sci U S A 1988;85: $637-40$.

[8] Allen J, Backstrom KR, Cooper JA, et al. Measurement of soluble transferrin receptor in serum of healthy adults. Clin Chem 1998;44:35-9.

[9] Virtanen MA, Viinikka LU, Virtanen MK, et al. Higher concentrations of serum transferrin receptor in children than in adults. Am J Clin Nutr 1999;69:256-60.

[10] Anttila R, Cook JD, Siimes MA. Body iron stores decrease in boys during pubertal development: the transferrin receptorferritin ratio as an indicator of iron status. Pediatr Res 1997; 41:224-8.

[11] Suominen P, Virtanen A, Lehtonen-Veromaa M, et al. Regression-based reference limits for serum transferrin receptor in children 6 months to 16 years of age. Clin Chem 2001; 47:935-7.

[12] Huebers HA, Beguin Y, Pootrakul P, Einspahr D, Finch CA. Intact transferrin receptors in human plasma and their relation to erythropoiesis. Blood 1990;75:102-7.

[13] Flowers CH, Skikne BS, Covell AM, Cook JD. The clinical measurement of serum transferrin receptor. J Lab Clin Med 1989;114:368-77.

[14] Beguin Y, Oris R, Fillet G. Dynamics of erythropoietic recovery after bone marrow transplantation: role of marrow proliferative capacity and erythropoietin production in autologous versus allogeneic transplants. Bone Marrow Transplant 1993;11:285-92.

[15] Beguin Y, Clemons G, Pootrakul P, Fillet G. Quantitative assessment of erythropoiesis and functional classification of anemia based on measurements of serum transferrin receptor and erythropoietin. Blood 1993;81:1067-76.

[16] Corazza F, Beguin Y, Bergmann P, et al. Anemia in children with cancer is associated with decreased erythropoietic activity and not with inadequate erythropoietin production. Blood 1998;92:1793-8.

[17] Beguin Y, Lampertz S, Bron D, Fillet G. Serum erythropoietin in chronic lymphocytic leukemia. Br J Haematol 1996; 93:154-6.

[18] Beguin Y, Yerna M, Loo M, Weber M, Fillet G. Erythropoiesis in multiple myeloma: defective red cell production due to inappropriate erythropoietin production. $\mathrm{Br} \mathrm{J}$ Haematol 1992;82:648-53.

[19] Cazzola M, Ponchio L, de Benedetti F, et al. Defective iron supply for erythropoiesis and adequate endogenous erythropoietin production in the anemia associated with systemiconset juvenile chronic arthritis. Blood 1996;87:4824-30.

[20] Beguin Y, Baron F, Fillet G. Influence of marrow erythropoietic activity on serum erythropoietin levels after autologous hematopoietic stem cell transplantation. Haematologica 1998;83:1076-81.

[21] Cazzola M, Guarnone R, Cerani P, Centenara E, Rovati A, Beguin Y. Red blood cell precursor mass as an independent determinant of serum erythropoietin level. Blood 1998;91: 2139-45.

[22] Cazzola M, Guarnone R, Cerani P, Rovati A, Ascari E. Congenital erythropoietin-dependent erythrocytosis responsive to theophylline treatment [letter; comment]. Blood 1998;91: $360-1$.

[23] Cappellini MD, Graziadei G, Ciceri L, et al. Butyrate trials. Ann NY Acad Sci 1998;850:110-9.

[24] Ledue TB, Craig WY. Serum concentrations of transferrin receptor in hereditary hemochromatosis. Clin Chem 1995; 41:1053-4.

[25] Schrezenmeier H, Noe G, Raghavachar A, Rich IN, Heimpel $\mathrm{H}$, Kubanek B. Serum erythropoietin and serum transferrin receptor levels in aplastic anaemia. Br J Haematol 1994; 88:286-94.

[26] Beshara S, Birgegard G, Goch J, Wahlberg J, Wikstrom B, Danielson BG. Assessment of erythropoiesis following renal transplantation. Eur J Haematol 1997;58:167-73.

[27] Singhal A, Cook JD, Skikne BS, Thomas P, Serjeant B, Serjeant $G$. The clinical significance of serum transferrin receptor levels in sickle cell disease. Br J Haematol 1993; 84:301-4.

[28] El Nawawy A, Massoud MN, El Bordiny M, Hegazy S. Evaluation of serum soluble transferrin receptors and erythropoietin levels as indicators for erythropoietic activity among multi-transfused beta-thalassemic patients. J Trop Pediatr 2002;48:33-8.

[29] Cazzola M, Borgna-Pignatti C, Locatelli F, Ponchio L, Beguin Y, De Stefano P. A moderate transfusion regimen may reduce iron loading in beta-thalassemia major without producing excessive expansion of erythropoiesis. Transfusion 1997;37:135-40.

[30] Tancabelic J, Sheth S, Paik M, Piomelli S. Serum transferrin 
receptor as a marker of erythropoiesis suppression in patients on chronic transfusion. Am J Hematol 1999;60:121-5.

[31] Loukopoulos D, Voskaridou E, Kalotychou V, Schina M, Loutradi A, Theodoropoulos I. Reduction of the clinical severity of sickle cell/beta-thalassemia with hydroxyurea: the experience of a single center in Greece. Blood Cells Mol Dis 2000;26:453-66.

[32] Beguin Y, Loo M, R'Zik S, et al. Quantitative assessment of erythropoiesis in haemodialysis patients demonstrates gradual expansion of erythroblasts during constant treatment with recombinant human erythropoietin. Br J Haematol 1995; 89:17-23.

[33] Beguin Y, Loo M, R'Zik S, et al. Early prediction of response to recombinant human erythropoietin in patients with the anemia of renal failure by serum transferrin receptor and fibrinogen. Blood 1993;82:2010-6.

[34] Bessho M, Hirashima K, Asano S, et al. Treatment of the anemia of aplastic anemia patients with recombinant human erythropoietin in combination with granulocyte colony-stimulating factor: a multicenter randomized controlled study. Multicenter Study Group. Eur J Haematol 1997;58:265-72.

[35] Martelli M, Ponchio L, Beguin Y, Meloni G, Mandelli F, Cazzola M. Pure red cell aplasia following peripheral stem cell transplantation: complete response to a short course of high-dose recombinant human erythropoietin. Haematologica 1994;79:456-9.

[36] Dore F, Bonfigli S, Gaviano E, Pardini S, Longinotti M. Serum transferrin receptor levels in patients with thalassemia intermedia during rHuEPO administration. Haematologica 1996;81:37-9.

[37] Cazzola M, Ponchio L, Beguin Y, et al. Subcutaneous erythropoietin for treatment of refractory anemia in hematologic disorders. Results of a phase I/II clinical trial. Blood 1992; 79:29-37.

[38] Cazzola M, Ponchio L, Pedrotti C, et al. Prediction of response to recombinant human erythropoietin (rHuEpo) in anemia of malignancy. Haematologica 1996;81:434-41.

[39] Ludwig H, Fritz E, Leitgeb C, Pecherstorfer M, Samonigg L, Schuster J. Prediction of response to erythropoietin treatment in chronic anemia of cancer. Blood 1994;84:1056-63.

[40] Hellstrom-Lindberg E, Ahlgren T, Beguin Y, et al. Treatment of anemia in myelodysplastic syndromes with granulocyte colony-stimulating factor plus erythropoietin: results from a randomized phase II study and long-term follow-up of 71 patients. Blood 1998;92:68-75.

[41] Pettersson T, Teppo AM, Siimes MA. Circulating transferrin receptor during erythropoietin medication of anemic patients with rheumatoid arthritis. Scand J Rheumatol 1996;25:321-4.

[42] Eschbach JW, Haley NR, Egrie JC, Adamson JW. A comparison of the responses to recombinant human erythropoietin in normal and uremic subjects. Kidney Int 1992; 42:407-16.

[43] van Iperen CE, Gaillard CA, Kraaijenhagen RJ, Braam BG, Marx JJ, van de WA. Response of erythropoiesis and iron metabolism to recombinant human erythropoietin in intensive care unit patients. Crit Care Med 2000;28:2773-8.
[44] Gareau R, Audran M, Baynes RD, et al. Erythropoietin abuse in athletes [letter]. Nature 1996;380:113.

[45] Biesma DH, van de Wiel A, Beguin Y, Kraaijenhagen RJ, Marx JJ. Erythropoietic activity and iron metabolism in autologous blood donors during recombinant human erythropoietin therapy. Eur J Clin Invest 1994;24:426-32.

[46] Krallis N, Cholevas V, Mavridis A, Georgiou I, Bourantas K, Andronikou S. Effect of recombinant human erythropoietin in preterm infants. Eur J Haematol 1999;63:71-6.

[47] Locatelli F, Zecca M, Beguin Y, et al. Accelerated erythroid repopulation with no stem-cell competition effect in children treated with recombinant human erythropoietin after allogeneic bone marrow transplantation. Br J Haematol 1993; $84: 752-4$.

[48] Baron F, Sautois B, Baudoux E, Matus G, Fillet G, Beguin Y. Optimization of recombinant human erythropoietin therapy after allogeneic hematopoietic stem cell transplantation. Exp Hematol 2002;30:546-54.

[49] Piron M, Loo M, Gothot A, Tassin F, Fillet G, Beguin Y. Cessation of intensive treatment with recombinant human erythropoietin is followed by secondary anemia. Blood 2001;97:442-8.

[50] Magnani M, Corsi D, Bianchi M, et al. Identification of blood erythroid markers useful in revealing erythropoietin abuse in athletes. Blood Cells Mol Dis 2001;27:559-71.

[51] Parisotto R, Gore CJ, Emslie KR, et al. A novel method utilising markers of altered erythropoiesis for the detection of recombinant human erythropoietin abuse in athletes. Haematologica 2000;85:564-72.

[52] Koistinen PO, Rusko H, Irjala K, et al. EPO, red cells, and serum transferrin receptor in continuous and intermittent hypoxia. Med Sci Sports Exerc 2000;32:800-4.

[53] Stray-Gundersen J, Chapman RF, Levine BD. "Living hightraining low" altitude training improves sea level performance in male and female elite runners. J Appl Physiol 2001; 91:1113-20.

[54] A randomized double-blind placebo-controlled study with subcutaneous recombinant human erythropoietin in patients with low-risk myelodysplastic syndromes. Italian Cooperative Study Group for rHuEpo in Myelodysplastic Syndromes. Br J Haematol 1998;103:1070-4..

[55] Kim SW, Luykx DM, de Vries S, Duine JA. A second molybdoprotein aldehyde dehydrogenase from Amycolatopsis methanolica NCIB 11946. Arch Biochem Biophys 1996; 325:1-7.

[56] Thorstensen K, Romslo I. Measurement of serum transferrin receptors in screening for hemochromatosis. Clin Chem 1992;38:1510.

[57] Baynes RD, Cook JD, Bothwell TH, Friedman BM, Meyer TE. Serum transferrin receptor in hereditary hemochromatosis and African siderosis. Am J Hematol 1994;45:288-92.

[58] Khumalo H, Gomo ZA, Moyo VM, et al. Serum transferrin receptors are decreased in the presence of iron overload. Clin Chem 1998;44:40-4.

[59] Akesson A, Bjellerup P, Vahter M. Evaluation of kits for measurement of the soluble transferrin receptor. Scand J Clin Lab Invest 1999;59:77-81. 
[60] Ahluwalia N. Diagnostic utility of serum transferrin receptors measurement in assessing iron status. Nutr Rev 1998;56: $133-41$.

[61] Punnonen K, Irjala K, Rajamaki A. Serum transferrin receptor and its ratio to serum ferritin in the diagnosis of iron deficiency. Blood 1997;89:1052-7.

[62] Olivares M, Walter T, Cook JD, Hertrampf E, Pizarro F. Usefulness of serum transferrin receptor and serum ferritin in diagnosis of iron deficiency in infancy. Am J Clin Nutr 2000;72:1191-5.

[63] Kotisaari S, Romppanen J, Penttila I, Punnonen K. The Advia 120 red blood cells and reticulocyte indices are useful in diagnosis of iron-deficiency anemia. Eur J Haematol 2002; 68:150-6.

[64] Choi JW, Pai SH. Reticulocyte subpopulations and reticulocyte maturity index (RMI) rise as body iron status falls. Am J Hematol 2001;67:130-5.

[65] Mast AE, Blinder MA, Gronowski AM, Chumley C, Scott MG. Clinical utility of the soluble transferrin receptor and comparison with serum ferritin in several populations. Clin Chem 1998;44:45-51.

[66] Niinikoski H, Koskinen P, Punnonen K, et al. Intake and indicators of iron and zinc status in children consuming diets low in saturated fat and cholesterol: the STRIP baby study. Special Turku Coronary Risk Factor Intervention Project for Babies. Am J Clin Nutr 1997;66:569-74.

[67] Skikne BS, Flowers CH, Cook JD. Serum transferrin receptor: a quantitative measure of tissue iron deficiency. Blood 1990;75:1870-6.

[68] Malope BI, MacPhail AP, Alberts M, Hiss DC. The ratio of serum transferrin receptor and serum ferritin in the diagnosis of iron status. Br J Haematol 2001;115:84-9.

[69] Cermak J, Brabec V. Transferrin receptor-ferritin index: a useful parameter in differential diagnosis of iron deficiency and hyperplastic erythropoiesis. Eur J Haematol 1998; 61:210-2.

[70] Gimferrer E, Ubeda J, Royo MT, et al. Serum transferrin receptor levels in different stages of iron deficiency. Blood 1997;90:1332-4.

[71] Brugnara C, Zurakowski D, DiCanzio J, Boyd T, Platt O. Reticulocyte hemoglobin content to diagnose iron deficiency in children. JAMA 1999;281:2225-30.

[72] Harthoorn-Lasthuizen EJ, van't Sant P, Lindemans J, Langenhuijsen MM. Serum transferrin receptor and erythrocyte zinc protoporphyrin in patients with anemia. Clin Chem 2000;46:719-22.

[73] Kohgo Y, Niitsu Y, Kondo H, et al. Serum transferrin receptor as a new index of erythropoiesis. Blood 1987;70:1955-8.

[74] Zhu YI, Haas JD. Response of serum transferrin receptor to iron supplementation in iron-depleted, nonanemic women. Am J Clin Nutr 1998;67:271-5.

[75] Brownlie T, Utermohlen V, Hinton PS, Giordano C, Haas JD. Marginal iron deficiency without anemia impairs aerobic adaptation among previously untrained women. Am J Clin Nutr 2002;75:734-42.

[76] Martini A, Ravelli A, Di Fuccia G, Rosti V, Cazzola M, Barosi G. Intravenous iron therapy for severe anaemia in systemic-onset juvenile chronic arthritis. Lancet 1994;344: 1052-4.

[77] Suominen P, Punnonen K, Rajamaki A, Irjala K. Serum transferrin receptor and transferrin receptor-ferritin index identify healthy subjects with subclinical iron deficits. Blood 1998;92:2934-9.

[78] Beguin Y, Grek V, Weber G, et al. Acute functional iron deficiency in obese subjects during a very-low-energy allprotein diet. Am J Clin Nutr 1997;66:75-9.

[79] Asobayire FS, Adou P, Davidsson L, Cook JD, Hurrell RF. Prevalence of iron deficiency with and without concurrent anemia in population groups with high prevalences of malaria and other infections: a study in Cote d'Ivoire. Am J Clin Nutr 2001;74:776-82.

[80] Lammi-Keefe CJ, Lickteig ES, Ahluwalia N, Haley NR. Day-to-day variation in iron status indexes is similar for most measures in elderly women with and without rheumatoid arthritis. J Am Diet Assoc 1996;96:247-51.

[81] Ferguson BJ, Skikne BS, Simpson KM, Baynes RD, Cook JD. Serum transferrin receptor distinguishes the anemia of chronic disease from iron deficiency anemia. J Lab Clin Med 1992;119:385-90.

[82] Semba RD, Kumwenda N, Hoover DR, et al. Assessment of iron status using plasma transferrin receptor in pregnant women with and without human immunodeficiency virus infection in Malawi. Eur J Clin Nutr 2000;54:872-7.

[83] Dimitriou H, Stiakaki E, Markaki EA, Bolonaki I, Giannakopoulou C, Kalmanti M. Soluble transferrin receptor levels and soluble transferrin receptor/log ferritin index in the evaluation of erythropoietic status in childhood infections and malignancy. Acta Paediatr 2000;89:1169-73.

[84] Wians Jr FH, Urban JE, Keffer JH, Kroft SH. Discriminating between iron deficiency anemia and anemia of chronic disease using traditional indices of iron status vs. transferrin receptor concentration. Am J Clin Pathol 2001;115: $112-8$.

[85] Reynolds P. Newborns have unique confounding factors regarding the TfR $-\mathrm{F}$ ratio. Arch Dis Child Fetal Neonatal Ed 2001;85:F146.

[86] Ho CH. The differential diagnostic values of serum transferrin receptor, serum ferritin and related parameters in the patients with various causes of anemia. Haematologica 2001; 86:206-7.

[87] Remacha AF, Sarda MP, Parellada M, Ubeda J, Manteiga R. The role of serum transferrin receptor in the diagnosis of iron deficiency. Haematologica 1998;83:963-6.

[88] Pettersson T, Kivivuori SM, Siimes MA. Is serum transferrin receptor useful for detecting iron-deficiency in anaemic patients with chronic inflammatory diseases? Br J Rheumatol 1994;33:740-4.

[89] Suominen P, Punnonen K, Rajamaki A, Irjala K. Evaluation of new immunoenzymometric assay for measuring soluble transferrin receptor to detect iron deficiency in anemic patients. Clin Chem 1997;43:1641-6.

[90] Suominen P, Mottonen T, Rajamaki A, Irjala K. Single values of serum transferrin receptor and transferrin receptor ferritin index can be used to detect true and functional iron 
deficiency in rheumatoid arthritis patients with anemia. Arthritis Rheum 2000;43:1016-20.

[91] Rimon E, Levy S, Sapir A, et al. Diagnosis of iron deficiency anemia in the elderly by transferrin receptor-ferritin index. Arch Intern Med 2002;162:445-9.

[92] Zoli A, Altomonte L, Mirone L, et al. Serum transferrin receptors in rheumatoid arthritis. Ann Rheum Dis 1994; 53:699-701.

[93] Nielsen OJ, Andersen LS, Hansen NE, Hansen TM. Serum transferrin receptor levels in anaemic patients with rheumatoid arthritis. Scand J Clin Lab Invest 1994;54:75-82.

[94] Revel-Vilk S, Tamary H, Broide E, et al. Serum transferrin receptor in children and adolescents with inflammatory bowel disease. Eur J Pediatr 2000;159:585-9.

[95] Junca J, Fernandez-Aviles F, Oriol A, et al. The usefulness of the serum transferrin receptor in detecting iron deficiency in the anemia of chronic disorders. Haematologica 1998;83: $676-80$.

[96] Noe G, Augustin J, Hausdorf S, Rich IN, Kubanek B. Serum erythropoietin and transferrin receptor levels in patients with rheumatoid arthritis. Clin Exp Rheumatol 1995;13: 445-51.

[97] Baumann Kurer S, Seifert B, Michel B, Ruegg R, Fehr J. Prediction of iron deficiency in chronic inflammatory rheumatic disease anaemia. Br J Haematol 1995;91:820-6.

[98] Feelders RA, Vreugdenhil G, Manger B, van Eijk HG, Swaak AJ. Serum transferrin receptor levels in anaemia of rheumatoid arthritis and effects of iron chelation treatment [letter]. Eur J Haematol 1994;52:61-2.

[99] Woith W, Nusslein I, Antoni C, et al. A soluble form of the human transferrin receptor is released by activated lymphocytes in vitro. Clin Exp Immunol 1993;92:537-42.

[100] Keevil B, Rowlands D, Burton I, Webb AK. Assessment of iron status in cystic fibrosis patients. Ann Clin Biochem 2000;37(Pt 5):662-5.

[101] Song JS, Park W, Bae SK, et al. The usefulness of serum transferrin receptor and ferritin for assessing anemia in rheumatoid arthritis: comparison with bone marrow iron study. Rheumatol Int 2001;21:24-9.

[102] van Tellingen A, Kuenen JC, de Kieviet W, van Tinteren H, Kooi ML, Vasmel WL. Iron deficiency anaemia in hospitalised patients: value of various laboratory parameters. Differentiation between IDA and ACD. Neth J Med 2001;59: $270-9$.

[103] Bultink IE, Lems WF, van de Stadt RJ, et al. Ferritin and serum transferrin receptor predict iron deficiency in anemic patients with rheumatoid arthritis. Arthritis Rheum 2001;44: 979-81.

[104] Ahluwalia N, Lammi-Keefe CJ, Bendel RB, Morse EE, Beard JL, Haley NR. Iron deficiency and anemia of chronic disease in elderly women: a discriminant-analysis approach for differentiation. Am J Clin Nutr 1995;61:590-6.

[105] Kivivuori SM, Anttila R, Viinikka L, Pesonen K, Siimes MA. Serum transferrin receptor for assessment of iron status in healthy prepubertal and early pubertal boys. Pediatr Res 1993;34:297-9.

[106] Carpani G, Buscaglia M, Ghisoni L, et al. Soluble transferrin receptor in the study of fetal erythropoietic activity. Am J Hematol 1996;52:192-6.

[107] Kling PJ, Roberts RA, Widness JA. Plasma transferrin receptor levels and indices of erythropoiesis and iron status in healthy term infants. J Pediatr Hematol Oncol 1998;20: 309-14.

[108] Means Jr RT, Allen J, Sears DA, Schuster SJ. Serum soluble transferrin receptor and the prediction of marrow aspirate iron results in a heterogeneous group of patients. Clin Lab Haematol 1999;21:161-7.

[109] Nagral A, Mehta AB, Gomes AT, et al. Serum soluble transferrin receptor in the diagnosis of iron deficiency in chronic liver disease. Clin Lab Haematol 1999;21:93-7.

[110] Fernandez-Rodriguez AM, Guindeo-Casasus MC, MoleroLabarta T, et al. Diagnosis of iron deficiency in chronic renal failure. Am J Kidney Dis 1999;34:508-13.

[111] Williams TN, Maitland K, Rees DC, et al. Reduced soluble transferrin receptor concentrations in acute malaria in Vanuatu. Am J Trop Med Hyg 1999;60:875-8.

[112] Beesley R, Filteau S, Tomkins A, et al. Impact of acute malaria on plasma concentrations of transferrin receptors. Trans R Soc Trop Med Hyg 2000;94:295-8.

[113] Menendez C, Quinto LL, Kahigwa E, et al. Effect of malaria on soluble transferrin receptor levels in Tanzanian infants. Am J Trop Med Hyg 2001;65:138-42.

[114] Mockenhaupt FP, May U, Stark K, Falusi AG, Meyer CG, Bienzle U. Serum transferrin receptor levels are increased in asymptomatic and mild plasmodium falciparum-infection. Haematologica 1999;84:869-73.

[115] Stoltzfus RJ, Chwaya HM, Montresor A, Albonico M, Savioli L, Tielsch JM. Malaria, hookworms and recent fever are related to anemia and iron status indicators in 0 - to 5-y old Zanzibari children and these relationships change with age. J Nutr 2000;130:1724-33.

[116] Kuvibidila S, Mark JA, Warrier RP, Yu L, Ode D, Tshefu KA. Soluble transferrin receptor as an index of iron status in Zaïrian children with malaria. J Trop Med Hyg 1995;98: $373-8$.

[117] Kivibidila S, Warrier RP, Ode D, Yu L, Tshefu KA. Lack of difference in iron status assessed by soluble transferrin receptor between children with cerebral malaria and those with non-cerebral malaria. J Trop Pediatr 1999;45:166-7.

[118] Ahluwalia N, Skikne BS, Savin V, Chonko A. Markers of masked iron deficiency and effectiveness of EPO therapy in chronic renal failure. Am J Kidney Dis 1997;30:532-41.

[119] Lorenzo JD, Rodriguez MM, Martin SS, Romo JM. Assessment of erythropoiesis activity during hemodialysis therapy by soluble transferrin receptor levels and ferrokinetic measurements. Am J Kidney Dis 2001;37:550-6.

[120] Tessitore N, Solero GP, Lippi G, et al. The role of iron status markers in predicting response to intravenous iron in haemodialysis patients on maintenance erythropoietin. Nephrol Dial Transplant 2001;16:1416-23.

[121] Loo M, Beguin Y. The effect of recombinant human erythropoietin on platelet counts is strongly modulated by the adequacy of iron supply. Blood 1999;93:3286-93.

[122] Beguin Y, Lipscei G, Thoumsin H, Fillet G. Blunted eryth- 
ropoietin production and decreased erythropoiesis in early pregnancy. Blood 1991;78:89-93.

[123] Akesson A, Bjellerup P, Berglund M, Bremme K, Vahter M. Serum transferrin receptor: a specific marker of iron deficiency in pregnancy. Am J Clin Nutr 1998;68:1241-6.

[124] Huddle JM, Gibson RS, Cullinan TR. The impact of malarial infection and diet on the anaemia status of rural pregnant Malawian women. Eur J Clin Nutr 1999;53:792-801.

[125] Choi JW, Pai SH. Change in erythropoiesis with gestational age during pregnancy. Ann Hematol 2001;80:26-31.

[126] Choi JW, Im MW, Pai SH. Serum transferrin receptor concentrations during normal pregnancy. Clin Chem 2000;46: $725-7$.

[127] Kuvibidila S, Yu LC, Ode DL, Warrier RP, Mbele V. Assessment of iron status of Zairean women of childbearing age by serum transferrin receptor. Am J Clin Nutr 1994;60:603-9.

[128] Rusia U, Flowers C, Madan N, Agarwal N, Sood SK, Sikka M. Serum transferrin receptors in detection of iron deficiency in pregnancy. Ann Hematol 1999;78:358-63.

[129] van den Broek NR, Letsky EA, White SA, Shenkin A. Iron status in pregnant women: which measurements are valid? Br J Haematol 1998;103:817-24.

[130] Klemow D, Einsphar D, Brown TA, Flowers CH, Skikne BS. Serum transferrin receptor measurements in hematologic malignancies. Am J Hematol 1990;34:193-8.
[131] Brada SJ, de Wolf JT, Hendriks D, Louwes H, van den BE, Vellenga E. Characterization of the erythropoiesis in myelodysplasia by means of ferrokinetic studies, in vitro erythroid colony formation and soluble transferrin receptor. Leukemia 1998;12:340-5.

[132] Bowen DT, Culligan D, Beguin Y, Kendall R, Willis N. Estimation of effective and total erythropoiesis in myelodysplasia using serum transferrin receptor and erythropoietin concentrations, with automated reticulocyte parameters. Leukemia 1994;8:151-5.

[133] Dowlati A, Loo M, Bury T, Fillet G, Beguin Y. Soluble and cell-associated transferrin receptor in lung cancer. Br J Cancer 1997;75:1802-6.

[134] Kohgo Y, Kondo H, Mogi Y, Niitsu Y. Mechanism and clinical significance of soluble hepatic cell-surface receptors. Targeted Diagn Ther 1991;4:305-19.

[135] Takubo T, Kumura T, Nakao T, et al. Clinical usefulness of combined measurements of serum soluble transferrin receptor levels and serum interleukin- 18 levels at determination of serum KL-6 levels in haematologic malignancies. Acta Haematol 2000;104:141-3.

[136] Stasi R, Zinzani L, Galieni P, et al. Clinical implications of cytokine and soluble receptor measurements in patients with newly-diagnosed aggressive non-Hodgkin's lymphoma. Eur J Haematol 1995;54:9-17. 